\title{
THE ROLE OF PESANTREN ON THE DEVELOPMENT ISLAMIC SCIENCE IN INDONESIA
}

\author{
M. Mujab \\ Fakultas Ilmu Tarbiyah dan Keguruan UIN Maulana Malik Ibrahim \\ Jl. Gajayana No. 50, Malang, 65144 \\ e-mail:mujab_muhammad@yahoo.com
}

\begin{abstract}
Abstrak: Peran Pesantren dalam Pengembangan Ilmu-ilmu Keislaman di Indonesia. Keberhasilan pesantren dalam mengembangkan ilmu-ilmu keislaman klasik telah memberikan kontribusi konkret bagi perkembangan pendidikan nasional. Akan tetapi, munculnya sekolah formal dan Perguruan Tinggi Islam terutama pasca kemerdekaan menjadikan pesantren harus beradaptasi dengan lingkungan barunya. Studi ini adalah literatur review hasil penelitian pada tiga pesantren: Tebuireng, Tambakberas dan Gontor; bagaimana peran masing-masing dalam mengembangkan ilmu keislaman melalui modernisasi pendidikan. Penelitian ini menyimpulkan bahwa Pesantren Tambakberas dan Tebuireng telah melakukan modernisasi dengan membuka sekolah formal dari tingkat MI dan SMP/MTs. sampai Perguruan Tinggi dan pada saat yang sama tetap menjaga tradisi klasiknya. Sebaliknya pola pendidikan di Pesantren Gontor lebih mudah beradaptasi karena sejak awal pendiriannya telah menerapkan sistem pendidikan Modern.
\end{abstract}

\begin{abstract}
The success of Pesantrens in developing Islamic sciences has significantly contributed to the development of national education. However, with the emergence of formal schools and universities, especially in the post-independence era the Pesantrens have to adapt to the novel system. This study is a literature review of research at three Islamic Boarding Schools namely, Pesantren Tebuireng, Tambakberas and Gontor; what role do they play in developing Islamic sciences through modernization of education. The research uncover that Pesantren Tambakberas Bahr Ulum and Tebuireng while maintaining the Islamic tradition each has modernized the educational system by providing formal schools at primary and elementary to university levels. However, adaptation to modern system is much easier for Modern Pesantren Gontor as it has applied modern educational system since the beginning of its establisment.
\end{abstract}

Keywords: pesantren, Islamic science, Indonesia, education 
MIQOT Vol. XXXVII No. 2 Juli-Desember 2013

\section{Introduction}

One of the most important institutions that have been playing great role in the development of Islamic sciences in Indonesia is called pesantren (traditional Islamic boarding school). Every Indonesian Muslim who wants to study Islam would definitely choose pesantren as the place of study due to its significance. Pesantren is one distinct characteristics of Islamic education in Indonesia.

The emphasis of education in pesantren is on the teaching of religious knowledge, the mental and spiritual training of students and social interaction. However, there are some pesantrens that provide some skills to the students like the plantation, husbandry, carpentry and some other skills. In its development, there are some modifications and improvement in the system of education in the pesantren. This is due to the unavoidable contact with the modern system of education. We notice that at present, there are some pesantrens that combine the system of madrasa and pesantren, so it creates a new order in the system of education in the pesantren. Itis important to remember that the contact between these two Islamic educational systems occurred only in the early 70s. The period before the 70s was marked by tendency the two sides to walk separately. ${ }^{1}$

There are thousands of pesantrens in Indonesia but, for the purpose of this study, we will only discuss some important pesantrens. This is so because the purpose of the study is to describe the important role played by the pesantren as a non-governmental institution in the development of Islam and its influence to the communities in Indonesia. The pesantrens that will be discussed are the pesantrens which are having historical roots and represent the general description of pesantren in Indonesia that includes the system of education used in the pesantren as well as the materials being taught there.

\section{Pondok Pesantren Tebuireng}

Tebuireng is one important pesantren in Indonesia that has been playing a very important role in the development of Islamic institutions in Indonesia. Besides, the contributions it made by producing many great personalities and ulamas, the Pesantren is also regarded as the pioneer in the establishment of many other pesantrens.

Pesantren Tebuireng was founded by KH. Hasyim Asy'ari in 1899. During the periods that have passed by, Pesantren Tebuireng has undergone many changes in its physical appearance as well as its educational system and also the up and downs in the number of students who study there. But one thing should be remembered that in this Pesantren, many ulamas and scholars have been produced. It is also one religious institution that,

${ }^{1}$ Marzuki Wahid, Suwendi, Saefuddin Zulu-I (ed.), Pesantren dan Masa Depan (Bandung: Pustaka Hidayah, 1999), p. 198. 
on one hand, can manage to keep its traditional characteristics and on the other, is able to develop new systems of education.

\section{The Background of Its Establishment}

Before we start the discussion on this Pesantren, it should be remembered that putting Pesantren Tebuireng as an object of case study is based on several reasons. The first reason is that Pesantren Tebuireng is a pesantren that has been playing a significant and dominant role in the preservation and development of traditional institutions in the $20^{\text {th }}$ century. It has also been playing the role of a resource-builder for the leadership in all the pesantrens in Java and Madura since the first decade of the 1900s. Second, the Pesantren has become the role model for the traditional pesantrens in the system of teaching, leadership, organization and the extra curricular activities. The Tebuireng also focussed its attention primarily on teaching of Quran as eternal programme of life. It also took up the teaching of Arabic grammar as the most importance subject since it held the key to the understanding of the Quran and other branches of Islamic sciences. Besides, Pesantren Tebuireng is known as the first Islamic traditional Institution that uses the class system before any other pesantrens. In short, we can say that Pesantren Tebuireng is the imâm, the leader, of pesantrens in Indonesia, especially in Java and Madura.

In the beginning the institution was a very simple construction, a building of 6 by 8 square meters. This building was divided into two parts, one room was used as the house of the kyai, Kyai Hasyim Asy'ari, and the other functioned as praying room for 28 students. With the increasing number of students studying there, the building was also increased in number and size.

At present, the building complex of Pesantren Tebuireng is built on an area of some two square hectares with some sport grounds and also an area of more than nine square hectares used as the Pesantren's farm. The complex consists of four building units: the first building is used as the main mosque located in the center of the complex, the second building is used as the house of the director of Pesantren Tebuireng, the third is used as the hostel for the students and the fourth unit is functioned as the madrasa and the university. At present, there are some three thousand students studying in this Institution. ${ }^{2}$

Within a period of 10 years after its establishment in 1899, Tebuireng became a centre of Islamic learning for students, not only of beginners but also of the students from other pesantrens who have received enough Islamic knowledge, but still wanted to learn more. The tremendous development of Pesantren Tebuireng could not be separated from the charisma and personal character of its founder, KH. Hasyim Asy'ari. He was known for his deep knowledge of Islam and his great personality. However, he was not the only

${ }^{2}$ Zamakhsyari Dhofier, Tradisi Pesantren (Jakarta: LP3ES, 1982), p. 102. 
sole factor for the tremendous development of Pesantren Tebuireng as a leading pesantren in Java. His aides like Kyai Ali Ma'sum, Kyai Baidhawi, Kyai Ilyas and Kyai Wahid Hasyim were also important personalities who have helped in nurturing the Pesantren Tebuireng. ${ }^{3}$

Like the pesantren in general, the method of teaching in Pesantren Tebuireng was sorogan (a system of teaching where the students will come forward to the teacher and read the materials given one by one). But this kind of system was no longer in use therealthough this system might still be in use in some traditional pesantrens. Between 1916 to 1934, Pesantren Tebuireng used a class system where there were seven classes that were further divided in to two stages. The first stage was called sifir awwal and the second was known as sifr thânî. These two stages were known as preparation stages where the students were being prepared with basic knowledge for the study in the next five years. The mastery of Nahw and sharf, as the basic requirement for anyone who wants to learn Arabic, was the main emphasizing in these two stages. ${ }^{4}$

In the period of 1916 to 1919, the curriculum in Pesantren Tebuireng was restricted to the teaching of religious sciences. But from 1919 onwards, some modern sciences were included in the curriculum like the introduction of subject's Indonesian language, mathematics and geography. From 1926, the Dutch language, world history and some other subjects were included in the curriculum. ${ }^{5}$

\section{Stages of Education}

Some significant improvements were apparently there during the leadership of the oldest son of KH. Hasyim Asy'ari, Kyai Wahid Hasyim. In 1933 he suggested five points for the improvement of Pesantren Tebuireng. Some of these suggestions were that he wanted the bandongan system (the method of teaching where the teacher read the materials and the students listening to him carefully and without any class system) to be replaced by a more systematic tutorial class and he wanted to add more general sciences to the Pesantren's curriculum so that it would be beneficial for the students once they graduated from the Pesantren. He also suggested that the teaching of classical books only to be offered by the students who really wanted to study them. The teaching of all these classical books to all the students would be useless and time wasting, because there were a number of students who came to study in the Pesantren not to learn about it but to know the modern sciences offered by the Pesantren's curriculum and receive some religious knowledge.

But this suggestion was turned down by K.H. Hasyim Asy'ari. The implementation of the suggestion would be very radical and would be creating some havoc and crisis in

\footnotetext{
${ }^{3}$ Ibid.

${ }^{4}$ lbid., p. 103.

5Ibid., pp. 104-105.
} 
the Pesantren. However, KH. Hasyim Asy'ari agreed with a suggestion to build a new madrasah called Madrasah Nizamiyah in 1934 where the general knowledge received some $70 \%$ of the total curriculum and 30\% for religious education. Another significant development in Pesantren Tebuireng was that some additional courses like the art of speech, language courses (the Dutch and English languages), typing, and some other skills that would be beneficial for the students in the future were introduced. Unfortunately, the Madrasah did not last long since Kyai Wahid Hasyim, who responsible for the running of Madrasah, did not pay much attention to it and instead he was busy with his position as the party leader, Nadlatul Ulama, as well as opening up his career in politics.

When the Indonesian declared its independence in 1945 and Soekarno was the first President of the new Republic, he chose KH Wahid Hasyim as his cabinet Minister for Religious Affairs during the period of 1949-1952. As a minister, KH Wahid Hasyimissued a decree on 20 January 1950 regarding religious education. Through the decree, he made religious education a compulsory subject in all educational institutions, both the governmental as well as private. He also established schools for religious teachers and judges in Malang, Aceh, Bandung, Bukit Tinggi and Yogyakarta. Besides, he set up governmental institutions for religious teachers in Aceh, Padang, Banjarmasin, Jakarta, Tanjungkarang, Bandung, Pamekasan and Salatiga. ${ }^{6}$ It was because of the contribution of KH. Wahid Hasyim that until this period, all institutions, private as well as governmental, have religious education in their curriculums.

Since 1950s Pesantren Tebuireng has improved the organization of its educational institutions. The madrasah was divided into different stages: Madrasah Ibtidaiyah (elementary school), Madrasah Tsanawiyah (junior secondary school), Madrasah Aliyah (senior secondary school) and Madrasah Mu'allimin. These divisions are present even today, only Madrasah Mu'allimin has been removed from the educational structure in 1964. During the leadership of KH. Yusuf Hasyim in 1967, the Pesantren established its own university called the University of Hasyim Asy'ari. This university was established to accommodate graduates from the Madrasah Aliyah in Pesantren Tebuireng and also from Madrasah Aliyah from another pesantrens. There are four departments in the University: Department of Syari'ah (Islamic Law), specialized in Islamic justice; Department of Da'wah (Islamic Propagation); Department of Tarbiyah (Education), specialized in religious education; and Department of Ushûluddin (Islamic Thought).

In 1971, Pesantren Tebuireng established a madrasah for the study of Qur'an. The emphasis of study in this madrasah is to produce graduates who have good mastery of Qur'an. The subjects of study are religious knowledge, Arabic language and qirâ'ah sab'ah (seven methods of reading the Holy Qur'an).

${ }^{6} I b i d .$, pp. 106-107. 


\section{The Method of Teaching}

The method of teaching in this madrasah was that in the first, second and third grade, they used group study. Each group had 7 students with one senior who acted as the right hand of the kyai. His main duty was to check the memorization of junior students in his group before sending them to the kyai for test. Qirâ'ah sab'ah was started when the students reached the fourth, fifth and sixth grade. At these grades, the students have completed the memorization of the whole chapters of the Holy Qur'an, 30 chapters. It means that before reaching the fourth grade, the students must have completed the memorization of the whole chapters of the Holy Qur'an. ${ }^{7}$

At the same time, Pesantren Tebuireng also opened a preparatory school that was divided into two stages. These preparatory classes were meant for those students who did not have any basic in Arabic or that their skill in Arabic was unsatisfactory. After passing these preparation classes, it was hoped that the students would be able to join theclasses in the Pesantren along with those students form Madrasah Tsanawiyah easily because they known the basic of Arabic language.

In the later development, Pesantren Tebuireng opened its private junior high school and senior high school in 1975. The establishment of these two schools was in the pace with the appearance of such type of schools outside the Pesantren. Hence, in order to prepare its graduates to be competitive with other graduates from the schools outside the Pesantren, knowledge in science and technology was also necessary. ${ }^{8}$

\section{The Development of Pesantren in Different Periods}

Pesantren Tebuireng has produced thousands of graduates who have spread all over Indonesia from the time it was established. Almost all the leaders of the pesantrens in Java and Madura are graduates from this institution. This has become possible because of the fact that Pesantren Tebuireng was established and led by great ulama, $\mathrm{KH}$. Hasyim Asy'ari. He was a Muslim scholar who was known for his mastery of hadith (tradition) and spent most of his time teaching and spreading Islamic knowledge. His mastery of Arabic language was also an additional aspect to support his subject of study. But after his death in 1947, Pesantren Tebuireng faced some drawbacks, especially in the teaching of classical books. Although the physical appearance of the Pesantren improved and the number of students kept on increasing, but the educational orientation of the Pesantren has shifted. Before the death of $\mathrm{KH}$ Hasyim Asy'ari, the orientation was on higher education while after his death, the stress was on basic education.

${ }^{7}$ Muhammad Ridlwan Nasir, Dinamika Sistem Pendidikan (Surabaya: Central Media, 1996), p. 235.

${ }^{8}$ Ibid., pp. 204-207. 
Fortunately, before the situation went out of control, K.H Idris recognized the situation. He is a son in law of $\mathrm{KH}$, Hasyim Asy'ari who started teaching in the Pesantren in 1953. He tried to introduce special training that focused on educating selected students. This system was very personal, not include to all students in Pesantren. The students should have a good mastery of Arabic language. First, the selected students should memorize the basic book on Arabic grammar, matan jurumiyyah, with additional books like sharah jurumiyyah, Asnawi and Kafrawi. Then, the student should memorize another book on Arabic grammar, Alfiyah ibn Mâlik that would be followed by the study of Asmuni (sharh Alfiyah) and Mughni Labîb (a book on Arabic grammar by Ibn Hisham)

Another change that occurred in the Pesantren was in its leadership. The kyai, did not have supreme control over the Pesantren. The policies and decisions in the Pesantren would be taken and discussed by the collective leadership, the board of kyai and teachers. This change occurred during the leadership of KH Yusuf Hasyim, ${ }^{9}$ when he formally established the board of kyai and the board of education. These two boards were responsible for the running of the Pesantren. KH. Yusuf Hasyim himself would be responsible for the treasury and the maintenance of the Pesantren. The leadership of KH. Yusuf Hasyim was regarded as a diversion from the tradition in the Pesantren where the kyai was the supreme leader of the pesantren and was responsible for the running of the pesantren. The kyai is also responsible for the process of teaching and learning in the pesantren and as the religious leader of the community. ${ }^{10}$

\section{Pesantren Bahrul Ulum Tambak Beras}

Bahrul Ulum is one of the oldest pesantrens in Jombang, a town in East Java. This Institution was founded by KH. Sihah, grandfather of KH. Hasyim Asy'ari in $1830 \mathrm{AD}$, and it was the first Islamic Institution that used the class system which introduced in 1920 . However, the sorogan and bandongan methods of teaching are also still being used.

This Pesantren experienced a tremendous development under the leadership of KH. Abdul Wahab Hasbullah, a prominent figure and the founder of Nahdlatul Ulama organization. The Pesantren has more than 3000 students, both boys and girls. ${ }^{11}$

${ }^{9} \mathrm{He}$ is the son of K.H. Hasyim Asy'ari who replaced the position of Khaliq Hasyim as the leader of the Pesantren in 1965. He was born in 1929 and was active in politics when he was young. He was the member of Hizbullah squad during the Japanese occupation of 1942-1945. He was also a member of the People's Representative Assembly and also a leader in Nadlatul Ulama. See, Dhorier. Tradisi Pesantren, p. 107.

${ }^{10}$ Ibid., pp. 108-109.

${ }^{11}$ Direktori Pesantren (Jakarta: P3M, 1986), p. 238. 


\section{The Establishment of Pesantren Bahrul Ulum}

Pesantren Bahrul Ulum was built in 1838 by KH. Sihah. He was the father in law of $\mathrm{KH}$. Uthman, the founder of Pesantren Gedang, the grandfather of $\mathrm{KH}$. Hasyim Asy'ari, the founder of the famous Pesantren Tebuireng. The development of Pesantren Bahrul Ulum was very slow. Though the Pesantren has been established since 1838, but until 1950 there were only 200 students enrolled in this Institution. This situation was contrary to Pesantren Tebuireng that within ten years after its establishment, there were about 2000 students studied there. The slow development of Pesantren Bahrul Ulum was because of the fact that the Pesantren was located in the heart of the city so the DutchGovernment, the colonial ruler of Indonesia at the time, always monitored every move made by the Pesantren.

The most significant development of Bahrul Ulum took place during the leadership of KH. Abdul Wahab Hasbullah, ${ }^{12}$ the son of KH. Hasbullah, who was born in 1888. The progress of the Pesantren was due to the personal character of KH. Abdul Wahab Hasbullah. It was his personality and his deep understanding of Islam that brought the Pesantren into a better position. Besides, he was also known as an important figure who had also participated in the birth of Nahdlatul Ulama organization. He was also active in politics.

It was during his leadership that the Pesantren introduced the class system. The old systems of bandongan and sorogan were not abandoned with the introduction of class system, it would be easier for teachers to group students into different groups or classes on the basis of their individual capability. This system is also known as madrasah system.

Pesantren Darul Ulum was a Pesantren with distinct characteristics and it was not only taught various kinds of religious matters but also taught about nationalismto its students. It has been proved during the Dutch military aggression in 1948 where many students from Pesantren Bahrul Ulum joined the Hizbullah squad to fight against the Dutch from occupying the independent Indonesia. ${ }^{13}$ This action was due to the fact that the Rais Am of Nahdlatul Ulama at the time, KH. Hasyim Asy'ari, issued a fatwa that said: to fight against the Dutch colonialism is a must and is equal to jihad, the holy war. Hence many students from different pesantrens in Java and Madura joined the Hizbullah squad to defend Indonesia from the aggression of the Dutch colonialism.

On 29 December 1971, KH Abdul Wahab Hasbullah passed away and the leadership of the Pesantren was taken up by his son, Muhammad Najib Wahab, a graduate from the Faculty of Law and Islamic Jurisprudence of al-Azhar University in Cairo.Under the leadership of KH. Najib Wahab, Pesantren Bahrul Ulum registered some improvements. This showed

${ }^{12} \mathrm{KH}$. Abdul Wahab Hasbullah received his early religious education from his father, $\mathrm{KH}$. Hasbullah, the leader of Pesantren Bahrul Ulum at the time. He started his journey of knowledge when he was only 13 years old by studying in various pesantrens in Java like Pesantren Langitan, Tuban, Pesantren Mojosari, Nganjuk, Pesantren Tebuireng and once he studied with KH Khalil of Bangkalan, Madura before leaving for Mecca to continue his study there.

${ }^{13}$ Nasir, Dinamika Sistem Pendidikan, p. 161. 
by the increasing number of the hostels for the students and the establishment of some new educational facilities. Besides, during the tenure of KH. Najib Wahab, the school for Qur'anic teaching was established. The students, who were interested in studying the Holy Book, would be able to continue in the madrasah which was established in 1980 .

However, improvements did not satisfy the Kyai. Because, those students who have graduated from the high school of Bahrul Ulum could not be retained to study in the Pesantren since there was no higher institution available. Then, the board of Pesantren Bahrul Ulum decided to establish an academy called Akademi Bahasa Arab (the Academy of Arabic Language) in 1983. In 1986, this academy was converted into Universitas Bahrul Ulum (Bahrul Ulum University), opening some new faculties and departments.

Unfortunately, when Bahrul Ulum was enjoying the advancement in almost every aspect, KH. Najib Wahab passed away in 1986. This pushed Pesantren into a crisis of leadership that was quickly resolved by establishing a collective board of teachers that would be responsible for the running of the Pesantren. This board had some members who were the close relative of KH. Abdul Wahab Hasbullah. ${ }^{14}$

\section{Stages of Education}

Pesantren Bahrul Ulum has several stages of education, ranging from the basic to the higher education. These stages of education in the Pesantren are as the following Madrasah Tsanawiyah (three years), Madrasah Aliyah (three years), Madrasah Mu'allimin (for boys, six years), Madrasah Mu'allimat (for girls, six years), Junior High School (three years), and Senior High School (three years).

\section{Madrasah Tsanawiyah and Aliyah}

Madrasah Tsanawiyah Bahrul Ulum is a madrasah that follows the curriculum provided by the State's Religious Affairs Department. In this curriculum, a madrasah will have $30 \%$ of religious education and $70 \%$ of general subject. The religious education includes the study of Qur'an, hadith, fiqh, akhlaq (ethics), Arabic and Islamic history. The rest, 70\% will be general knowledge. This kind of curriculum is also applied in the Madrasah Aliyah. The only difference between the two is that Madrasah Aliyah is a higher than Madrasah Tsanawiyah (Madrasah Aliyah is a Senior High School while Madrasah Tsanawiyah is Junior High School). This State policy of education in the madrasah is a real disadvantage for the madrasah as an institution. Besides, differentiating itself from the mainstream of education will not be beneficial for the students since it would be impossible for them to continue to the higher education. The tendency among students and parents is that after completing the education in the Madrsah, the students hope that they will be able to study in a higher

${ }^{14}$ Ibid., p. 165. 
institution. Another reason is that not only that the religious education is $30 \%$ of the total curriculum, the value of the materials given is also very light. This material will help the students to know the 'skin' only and not the meaning inside. ${ }^{15}$

To cover this disadvantage, the Bahrul Ulum imparts the students some extra religious education. This step has been taken by providing compulsory lectures to the students on religious knowledge with the help of some religious books held in their free periods. The halaqah system of teaching is used in this process. This step also has been taken by some other pesantrens that have the same curriculum in their madrasahs.

This lecture is held everyday after prayers. In a halaqah system, the teacher read the book and the students gather around him and to write notes. The explanation from the teacher is the most importantaspect in this kind of learning system. Without the presence of teacher and without any clear of his explanation, the students will find it difficult to study.

The weakness of this system is no student attendance list and no evaluation process. Only some senior students who have better knowledge and understanding of Arabic grammar usually follow this halaqah. Although many have accepted that this system of learning is having some weaknesses, but till now, there is no other alternative system to replace it. Hence the system is still widely used in almost pesantrens in Indonesia.

\section{Madrasah Mu'allimin and Mu'allimat}

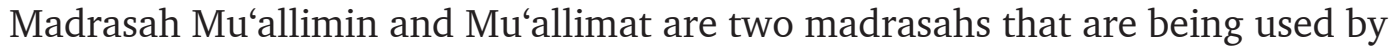
Pesantren Bahrul Ulum'as its formal educational unit since 1954. These two madrasahs have certain distinct characteristics. This is due to the curriculum used in the madrasah where in an ordinary madrasah, the religious education is having a smaller portion in its curriculum as compared to the curriculum in these two madrasahs. The great emphasize on religious education in these madrasahs has produced graduates having sound knowledge on religion as compared to the graduates from ordinary madrasahs. Besides, the graduates from these madrasahs have same opportunity and possibility to study in higher education institutions as the graduates from ordinary madrasahs since they are also eligible for it. ${ }^{16}$

\section{Junior and Senior High Schools}

The establishment of these two schools in Bahrul Ulum was due to the demand of the parents of the students in Pesantren. They demanded that the Pesantren should provide more chances to students to go for higher education by establishing an institution that will give general knowledge than the religious knowledge only. Thus the idea of the establishment

\footnotetext{
${ }^{15}$ Ibid.

${ }^{16}$ Ibid., pp. 173-74.
} 
originated that implementation of this idea, however, created its own problems since they have to arrange extra classes for the students so that they would also able to acquaint with religious knowledge. This extra class held by the pesantren by holding halaqah for the students has been the advantageous for the graduates from the madrasahs as compared to the graduates from ordinary madrasahs. Besides receiving general knowledge as their counterparts in ordinary school, the students in the madrasah run by pesantren are also receiving better religious education and also have the same chance to get higher education after the completion of their schooling.

\section{The Religious Books Used in Pesantren Bahrul Ulum}

In general, the books taught in the Pesantren Bahrul Ulum and pesantrens in Indonesia are uniform. They use the same books in teaching the students about the religious knowledge. This uniformity in the pesantrens in Indonesia is because of the fact that pesantren is an institution in Indonesia that has specialize itself in religious teaching. There are, however, some differences in these pesantrens in terms of subjectof specialization. Some pesantrens teach certain branches of Islamic science like fiqh, tafsîr and nahw (Arabic grammar) while others have specialized in other branches. However, this does not mean that the pesantrens are neglecting the basic function of pesantren as religious institution by not providing the students the basic knowledge they need. Hence they would still provide the students the basic knowledge of Islam in their syllabus though they have specialized in certain branches of knowledge.

In general, the books taught in these pesantrens are classical books, popularly known as kitab kuning (yellow book). The books being taught in Pesantren Bahrul Ulum are the following based on the stages of education:

\section{Madrasah Tsanawiyah}

1. Mabâdi' al-Fiqhiyah

2. Aqîdah al-'Awwâm

3. Hidâyat al-Shibyân

4. Muhâwarat al-Athfâl

5. Tuhfat al-athfâl

6. Tashîl an-Nahwi

7. Amtsilah Tasrîf S. Badul 'Amal

9. Lughat al-Arabiyah

10. Al-Akhlâq lil Banât

11. Fathul Qarîb

12. Nahww al-Wâdhih

13. Jawâhir Kalamiyah 
MIQOT Vol. XXXVII No. 2 Juli-Desember 2013

14. Muhâdastah Awwaliyah

15. Nûrul Yaqîn

16. Hadîts Arba'în

17. 'Imrithi

18. Iddat Farid

19. Târîkh al-Islâm

20. Bulûghul Marâm

21. Takhrîr

22. Alfiah

23. Tafsîr Jalâlain

24. Sullam al-Lughat al-Aarabiyah

\section{Madrasah Mu'allimin dan Mu'allimat:}

1. Fath al-Mu'în

2. Fath al-Wahâb

3. Alfiah Ibn Mâlik •

4. Bulûgh al-Marâm

5. Târîkh al-Islâm

6. Qirâ'at Tadrîjiyah

7. Qirâ'at Râsyidah

8. Tafsîr Jalâlain

9. HUshûl al-Hamîdiah

10. Qawâ'id al-Lughah al-'Arabiyah

11. Muzakkirât

12. Jawâhir al-Bukhârî

13. Jauharah al-Maknûn

14. Waraqât

15. Tajrîd al-Shorîkh

16. Al-Sullam

17. Baiquniyah

18. Farâ'id al-Bahiah

19. Tarbiyah wa al-Tahzîb

20. Tarbiyah Adabiyah

21. Durûs Falakiyah

22. Sullam Nirain. ${ }^{17}$

${ }^{17}$ Mahmud Yunus, Sejarah Pendidikan Islam di Indonesia (Jakarta: Mutiara Sumber Widya Jakarta 1995), p. 246. 
Pesantren Bahrul Ulum is one of Islamic institutions in Indonesia that has been a place of study of many great personalities. Many alumni of the Pesantren have been successful in their live as many of them have became teachers, members of civil service and members of social organization spread all over Indonesia. Hence the Pesantren has got its place in the hearts of the Indonesian people as an ideal place for religious study.

\section{Pondok Modern Darussalam Gontor Ponorogo}

Pesantren Darussalam is located in Gontor village, Merak district, Ponorogo, a town in East Java Province. This pesantren was built in an area of 8.5 hectare comprising of three houses for the guardians, two mosques, nine hostels for students with 450 rooms. There are some 2600 male students in the Pesantren. Besides, there are 6 houses for the teachers, three guesthouses, one meeting hall, one clinic, two stores and four school buildings.

The institution was built in 1926 by three brothers, KH. Zarkasi, KH. Sahal and KH. Fanani, based on the idea of creating a modern religious institution that will providethe students more chances to compete with the students and graduates from other institutions so that there would be some improvement in the quality of young Muslims to face the new challenges in the modern life. The model of education used in the Pesantren has given an inspiration for others to establish similar institutions in other parts of Indonesia.

\section{The Background of the Establishment}

The idea of establishing the "Darussalam, Gontor" came up before the meeting held by Muktamar Alam Islami in Mecca in 1926. Indonesia, as the most populous Muslim country, also participated in the conference. Hence a meeting was held to decide the delegation to be sent to Muktamar. Two persons would be selected as the Indonesian delegation and the member of the delegation should have good mastery of English as well as Arabic language. However, there was not even a single participant in the meeting who fulfilled the criteria. Then the board of meeting finally decided to choose two persons, H. Oemar Said Cokroaminoto, who was good in English, and KH. Mas Mansur who was fluent in Arabic, as the member of the Indonesian delegation for Muktamar held in Mecca. From the incident in this meeting, an idea to establish new Islamic institution came up, that will provide young Muslims better religious as well as general or modern knowledges.

The three brothers, inspired by the situation in the meeting, decided to start their work to establish an institution that would help young Muslims to be acquainted withreligious as well as non-religious knowledge. The establishment of Darussalam was the result of this idea. The system of education used in this institution was the combination of several systems used in different institutions like the al-Azhar University in Cairo, for its role as the center of Islamic learning, Pondok Sanggit in North Africa for its various scholarships for its students, the Aligarh Muslim University, India, for its ability to get along with the demand 
MIQOT Vol. XXXVII No. 2 Juli-Desember 2013

of time and its reformist tendency and Shanti Niketan of Rabindranath Tagore in India for its ability in preserving the culture and love for peace. ${ }^{18}$

\section{The Development of the Pesantren in Different Periods}

There have been so many developments that have taken the Darussalam Gontor to this stage. It has been through a long and tiring process to survive and adjust itself with the time and to be a role model for many new pesantrens built later. Many pesantren that have been built in the later period, especially in the 80 s, followed the method and system in this institution. This tendency to use the Gontor's system in new pesantrens might be because of the fact that many of the alumni established these new pesantrens. Besides, the board of Pesantren Gontor also provides helps for the establishment of new pesantrens by sending its alumni to teach in these new pesantrens and to provide the new pesantrens with the syllabus and the material to be taught there. Hence uniformity is created through this process.

The development of Darussalam Gontor can be divided into three different phases from the time of its establishment in 1926. The first phase occurred between 1926 and 1936 where there was a process of creating a religious community in the area where the Pesantren was built. An early religious education for young children was held as a preparation to create educated members of community and to make them aware of their duties and responsibilities as a religious community.

The second phase was from 1937 to 1954 where the education in the Pesantren was concentrated on Tsanawiyah and Aliyah levels (junior and senior high schools respectively). It means that the students who wanted to study in the Pesantren should have passed elementary education and the duration of study was three years, three years shorter as against the present six years.

The third phase was between 1945 to 1954 where the duration of study in Pesantren Gontor was increased from three years to six years. This phase was marked by the establishment of Kulliatul Mu'allimin al-Islamiyah. With this Kulliat, the students who have passed junior high school can directly apply to class four by clearing an entrance test. It was only in 1963 that Pesantren Gontor opened its own university known as Darussalam Institute with three years duration of study.

Another important development at Darussalam Gontor is that since 1957, the graduates from KMI (Kulliyat Mu'allimin al-Islamiyah) are eligible for applying to graduate course in Al-Azhar University as well as the University of Cairo in Egypt. ${ }^{19}$ Besides, there are many graduates from Darussalam Gontor who study in foreign universities, especially the universities in the Middle East, and many of them have got important posts in the government.

\footnotetext{
${ }^{18}$ M. Dawam Rahardjo, Pesantren dan Pembaharuan (Jakarta: LP3ES. 1995), pp. 135-136.

${ }^{19}$ Ibid.,pp. 141-142.
} 


\section{The Curriculum and Activities in Pesantren Darussalam Gontor}

Pesantren Gontor is a pesantren of distinct characteristics. It has differentiated itself from the traditional pesantrens in order to create a distinct atmosphere for producing graduates of distinct characteristics. The programs and syllabus in the Pesantren are meant for producing able graduates in religious as well as non-religious knowledge.

Pesantren Gontor has two stages of education, Kulliyat Mu'allimin Islamiyah (KMI) with the duration of 6 years and Darussalam Institute, an institute having a status of university that offers graduate degree, in three years. There is one distinct characteristic of Pesantren Gontor that it has a very high discipline. The students must speak either Arabic or English daily in the complex andonce they are found to speak in a language other than these two, a sanction will be given to the student and the sanction varies depending upon the mistake of the student. ${ }^{20}$ The curriculum is followed in the Pesantren Gontor:

\section{The Curiculum of Arabic in Pesantren Darussalam Gontor ${ }^{21}$}
1. Arabic language
: All the classes, from Ito VI
2. Imlak
: All the classes except class V and VI
3. Composition
: All classes
4. Nahw(grammar)
: All classes except class I
5. Caligraphy
: All classes except class I and VI
6. Balaghah (rhetoric)
: For class V and VI only
7. Adab al-Lughah
: For class V and VI only
(literature)

\section{Religious Science}
1. Alqur'an
: For class I and II
2. Tajwid
: For class I and II
3. Tafsîr
: All classes, Ito VI
4. Hadith
: All classes
5. Ilmu Hadith
: Class V and VI only
6. Ushûl Fiqh
: All classes except class I and II
7. Fiqh
: All classes
8. Ilmu Mantiq
: Class VI only
9. Tarikh Islam
: All classes except class V and VI
10. Tauhid/Akidah
: All classes, Ito VI

\footnotetext{
${ }^{20}$ Mastuhu, Dinamika Sistem Pendidikan Pesantren (Jakarta: INIS, 1994), pp. 121-122.

${ }^{21} Y u n u s$, Sejarah Pendidikan Islam, p. 251.
} 
MIQOT Vol. XXXVII No. 2 Juli-Desember 2013

\section{General Knowledge}

1. Algebra

2. Arithmatics

3. Science

4. Biology

5. History

6. Geography

7. Psychology

8. Teaching

9. Administration

10 English language

11 Indonesian language
: All classes

: All classes

: All classes

: Class I and II

: All classes

: All classes

: From class IV to VI

: For class V and VI only

: Class III, IV and V

: All classes

: All classes

Pesantren Gontor has been known for its high discipline in everyday activities. This has been shown in the rules and regulations for the students to comply with in their everyday activities. The rules and regulation of the Pesantren are the following:

The Daily Activities of the Students in the Pesantren Gontor ${ }^{22}$

\begin{tabular}{|c|l|l|}
\hline NO & \multicolumn{1}{|c|}{ TIME } & \multicolumn{1}{c|}{ ACTIVITIES } \\
\hline 1 & 04.00 & $\begin{array}{l}\text { Get up, take a bath, Morning Prayer together, reading the Qur'an, } \\
\text { repeating the lesson, breakfast, ready for school }\end{array}$ \\
\hline 2 & $05.30-06.30$ & Exercise \\
\hline 3 & $06.30-06.45$ & Breakfast, go to school \\
\hline 4 & $07.00-12.30$ & School time \\
\hline 5 & 12.30 & $\begin{array}{l}\text { Midday Prayer, lunch } \\
\text { Relaxing by reading (nap is prohibited) }\end{array}$ \\
\hline 6 & $12.30-14.00$ & $\begin{array}{l}\text { Continue the study in school, or following the Arabic/English } \\
\text { course and additional lesson, Afternoon Prayer }\end{array}$ \\
\hline 7 & $14.00-15.00$ & Sport, extra curricular like boy scout, drama, etc. \\
\hline 8 & $15.30-17.15$ & $\begin{array}{l}\text { All the students should gather in the mosque to perform Sunset } \\
\text { Prayer together }\end{array}$ \\
\hline 9 & $17.15-17.45$ & Sunset Prayer, reading the Qur'an (30 minutes), dinner \\
\hline 10 & $17.45-18.30$ & Preparation for Evening Prayer in the mosque \\
\hline 11 & $18.30-19.99$ & $\begin{array}{l}\text { Studying, repeating the previous lesson and preparing next day } \\
\text { lesson }\end{array}$ \\
\hline 12 & $19.10-22.00$ & $\begin{array}{l}\text { Resting, sleeping. The amount of sleep for every student should } \\
\text { not be less than 6 hours and should not exceed 8 hours }\end{array}$ \\
\hline 13 & $22.00-04.00$ & Resting. \\
\hline
\end{tabular}

${ }^{22}$ Mastuhu, Dinamika Sistem Pendidikan Pesantren, pp. 122-123. 
M. Mujab: The Role of Pesantren on The Development Islamic Science in Indonesia

Besides, there are also weekly activities in Pesantren Gontor:

1. Morning exercise on every Tuesday and Friday mornings, from 05:30 - 06:30

2. Speech exercise in English on every Sunday night from 19:20 - 21:00

3. Speech exercise in Arabic on every Thursday morning from 11:00 - 12:30

4. Speech exercise in Indonesian on every Thursday evening from 19:20 - 21:00

5. Boy scout on every Thursday afternoon

Though the Darussalam has a very high discipline for its students but in terms of religious understanding, the graduates of this Pesantren are less capable as compared to the graduates from traditional pesantrens. However, they win over the graduates from traditonal pesantrens in terms of their language skill. This has been proved with many of its alumni who study in the Middle East more easily and greater in number as compared to the graduates from traditional pesantren.

Darussalam is an Islamic institution that consistently develops its own idealism and braving itself in breaking the age-old tradition of religious teaching in Indonesia. The aim of this institution is to develop a high character, a broad knowledge, a sound body and independent thinking. With the help of visiting teachers from al-Azhar in Cairo, pupils are taught to speak Arabic in such a way that some of them continue their study in Cairo without difficulty.

Many new Islamic thinkers in Indonesia who studied in this institution have showed this evident. Former pupils of this Institution are, for instance, KH. Prof. Idham Chalid, exminister and chairman of Indonesia's Peoples'Consultative Assembly and Prof. Dr. Nurcholish Madjid, an Indonesian liberal thinker and the founder of Paramadina Mulya University in Jakarta, are two prominent personalities that have been born from the Pesantren. ${ }^{23}$ The Indonesian government is, of course, concerned with this Islamic institution by granting subsidies which depend on certain conditions.

With the development of modern education, the number of pesantren is also increasing. Improvement in the economic life of the Indonesian people has brought the process of modernization in the pesantrens. The process is related to development since the pesantren, is charging the fees monthly from its students for its running. The fees vary from one pesantren to another. However, the government also provides some financial help to certain pesantrens. This financial help from the government or from certain individuals is not permanent and depends on the situation. Hence pesantren has to take a decision to support itself independently. The monthly fee from student is the only answer available. This monthly fee helps the pesantren in providing better facilities. So far, there is no pesantren that provides free education to the students.

${ }^{23}$ B.J. Boland, The Struggle of Islam in Indonesia (Leiden: Martinus Nijhoff, 1971), p. 117. 


\section{Popular Books of Tafsir Used in the Pesantrens in Indonesia}

According to the result of a survey by a Dutch scholar, Van den Berg, there are only a few Tafsîrs used in the pesantrens in Indonesia. Tafsir was a subject of study that lacked the interest of the Muslims in Indonesia till the $19^{\text {th }}$ century. It was only after the launch of reform movement with a slogan of "return to Qur'an and Hadith" that echoed from Egypt to Indonesia spear headed by Muhammad 'Abduh, many ulama's in Indonesia started paying more attention to the study of tafsir.

The limited number of Tafsirs used in Indonesia can be seen in the table. Jalâlain is the most widely used Tafsir in Indonesia. This is followed by Tafsîr Baidâwî, Tafsîr al-Munîr (written by Shaikh Nawawi Banten) and Tafsîr Ibn Katsir. A tafsir by Muhammad 'Abduh and Rashid Ridhâ, Tafsîr al-Manâr, and Tafsîr al-Marâghî, written by Ahmad Mushtafa alMarâghî, are two Tafsirs by modernists known by the Indonesian Muslims. Only recently a few number of pesantrens in Indonesia have made these two Tafsirs part of their syllabus. These two Tafsirs are yet to be acceptable to the Muslims in the pesantren. ${ }^{24}$ This has been shown by an incident when the great KH. Hasyim Asy'ari forbade his students to read Tafsîr al-Manâr of Muhammad 'Abduh while he himself studied the Tafsir. The reason behind the prohibition was that the Tafsir has criticized traditional ulamas.

A tafsir by Zamakhsyârî called Tafsîr al-Kasysyâf does not have much approval of the Indonesian Muslim scholars in Indonesia because of the fact that he was a Mu'tazilite.There are some tafsirs by Indonesian ulamas that are popular in the pesantren in Indonesia. The oldest tafsir known as Tarjumân al-Mustafid was written by Indonesian ulama called 'Abd Rauf bin 'Ali al-Jawi al-Fansuri al-Sinkili. This tafsir was written in Malay and had been widely used in Indonesia for more than three decades. ${ }^{25}$ Al-Iklil fì $M a$ ' rifah Ma 'âni al-Tanzîl by KH. Misbah bin Zain al-Mustafa, comprising of 30 volumes, 4800 pages and al-Ibriz li Ma'rifati al-Tafsîr by KH. Bisri Mustafa (Rembang), comprising of 3 big volumes, are among the popular tafsirs in Indonesia. These two Tafsîrs are better to be called as the translation of the Qur'an than tafsir.

However, the word tafsir was included in the title of these two translations to show that these books were written with certain degree of explanation so they deserved to be known as tafsirs. ${ }^{26}$ A great Indonesian modernist, Prof. Dr. Buya HAMKA has also written a tafsir called Tafsir al-Azhar, comprising of 30 volumes. This Tafsir was also widely accepted by the Indonesian Muslims, especially by Muslim academicians.

\section{p. 159.}

${ }^{24}$ Martin van Bruinessen, Kitab Kuning, Pesantren dan Tarekat (Bandung: Mizan, 1999),

${ }^{25}$ Azyumardi Azra, Jaringan Ulama Timur Tengah dan Kepulauan Nusantara Abad XVII dan XVIII (Bandung: Mizan, 1994), p. 204.

${ }^{26} I b i d .$, p.159. 
M. Mujab: The Role of Pesantren on The Development Islamic Science in Indonesia

The books of Tafsir are popular in Pesantrens in Indonesia

\begin{tabular}{|c|c|c|c|c|c|c|c|}
\hline $\begin{array}{l}\text { Region Number } \\
\text { of Pesantren }\end{array}$ & $\begin{array}{c}\text { Suma- } \\
\text { tera } \\
4 \\
\end{array}$ & $\begin{array}{c}\text { S.Kalimantan } \\
3\end{array}$ & $\begin{array}{c}\text { West } \\
\text { Java } \\
9 \\
\end{array}$ & $\begin{array}{c}\text { Center } \\
\text { of Java } \\
12 \\
\end{array}$ & $\begin{array}{c}\text { East } \\
\text { Java } \\
18 \\
\end{array}$ & $\begin{array}{c}\text { Total } \\
46\end{array}$ & Level \\
\hline Tafsin & & & & & & & \\
\hline Tafsîr Jalâlain & 4 & 1 & 9 & 9 & 16 & 39 & Aliyah \\
\hline Tafsîr al-Munîr & 0 & 1 & 3 & 2 & 5 & 11 & Aliyah \\
\hline Tafsîr Ibn Katsir & 1 & 0 & 3 & 0 & 3 & 7 & Aliyah \\
\hline Tafsîr Baidhâwî & 1 & 0 & 1 & 2 & 0 & 4 & Aliyah \\
\hline Jami`al-Bayân & 0 & 0 & 2 & 0 & 0 & 3 & Khawash \\
\hline Marâghi & 0 & 0 & 2 & 1 & 0 & 3 & \\
\hline Tafsîr al-Manâr & 0 & 0 & 2 & 0 & 1 & 3 & Aliyah/ \\
\hline Tafsir DEPAG & 0 & 0 & 0 & 1 & 1 & 2 & $\begin{array}{l}\text { Khawash } \\
\text { Khawash } \\
\text { Tsanawiyah }\end{array}$ \\
\hline $\begin{array}{l}\text { 'Ilm Tafsîr } \\
\text { Itqân }\end{array}$ & 0 & 0 & 2 & 0 & 1 & 3 & \\
\hline Itmam al-Dirâyah & 0 & 0 & 0 & 0 & 2 & 2 & Aliyah \\
\hline
\end{tabular}

\section{Hadith and Science of Hadith}

The study of hadith is a subject that is very popular among the Indonesian Muslims. However the populartiy of hadith is far behind the popularity of fiqh and sufism. Different kinds of books on hadith are available in pesantrens in Indonesia. Many of these books became the syllabus of these pesantrens and some of these are being regularly read in the month of Ramadhan in the pesantrens. These are Shahîh $\underline{h}$ al-Bukhârî and Shahîh $\underline{h}$ Muslim that are read and finished within one month but wihout any further understanding of them. Muwaththa' and Sunan Abû Dâwûd are two other books of hadith that have been recently introduced in these pesantrens. Other books of hadith like Sunan Ibn Majah and Sunan Tirmizi only available in the libraries as the reference books.

Shahîh $\underline{h}$ al-Bukhârî and Shahîh $\underline{h}$ Muslim are two most popular books in Indonesia and are used as the muqarrar in many pesantrens. Bulûgh al-Marâm, a collection of hadith by Ibn Hajar al-'Asqalânî (d. 852/1449AD) is placed second rank. This book has been translated into local language, Javanese, by Subki Masyhadi from Pekalongan, Central Java. Subul alSalâm, an explanation of Bulûgh al-Marâm by Muhammad ibn Ismâil al-Kahlânî (d.1182/ $1769 \mathrm{AD}$ ), is also popular and has also been translated into Indonesian. Two books of selection from Shahîh al-Bukhârî, Tajrîd al-Shârih by Syihab al-Din Ahmad al-Syarji al-Zabidî (d. 893H/ 1488) and Jawâhir al Bukhârî by Musthafa M. Umarah, are two books of hadith that are part of the syllabus of many traditional pesantrens in Java. ${ }^{27}$

${ }^{27}$ Bruinessen, Kitab Kuning, p. 61. 
Besides, there are also many other books of hadith that are read and used in the Pesantren. These books like Riyâdh al-Shâlihîn, Hadith Arbaîn, a collection of hadith by Imam Nawawi, Tankikh al-Qaul, Mukhtarât al-Ahâdith and Ushfuriyah. The last three books are compulsory books on hadith in almost pesantrens. However, it should be kept in mind that a serious study of hadith is yet started in Indonesia. The interest for the study of hadith is appearing to develop among the Indonesian Muslims along with the insertion of Wahabi movement in Indonesia.

The standard books of hadith in Indonesia are Baiquniyah by Thaha bin Muhammad al-Fattuh al-Baiquni (d.1080H/1669) along with its explanation (sharh ) and Minhâj alMughith, a book on hadith by the ulama of al-Azhar, Hafiz Hasan Mas'udi. Two standard books of hadith used in India, Muqadimah Ibn Shalah and Nuhbah al-Fikr, are not generally used in Indonesia. It was only recently book like Minhâj Zawi M-Nazar, the explanation (Sharh) of Nazam Alfiyah Suyuthî by Muhammad Mahfud al-Turmusi is used as a compulsory book in traditonal pesantrens.

\section{Popular Books on Fiqh and Ushûl Fiqh}

Fiqh is the most popular subject of study in Indonesia. It is because of its importance in the daily life of the community. The popularity of fiqh among the Indonesian Muslims has made the subject the backbone of the pesantrens in Indonesia.

The popularity of fiqh in Indonesia is not without any reason. The contribution by Shaikh Nawawi Banten and Shaikh Mahfud Al-Turmusi in the early $19^{\text {th }}$ century to the development of fiqh cannot be undermined. They have written books in a simple and clear language have helped ordinary Muslims to understand the materials easily. They were also teachers for the generation of ulamas in the later period. However, great Indonesian ulamas before them like Hamzah al-Fansuri (d. 1590) and Syamsuddin Sumatrani (d.1630), both were from Aceh, and also Nuruddin al-Raniri (died in India in 1659) and Abdurrauf al-Singkli. These ulamas left some noted works on fiqh but they were the strict followers of Sufism. Hence it was only after the emergence of great Shaikh Nawawi Banten and Shaikh Mahfud al-Turmusi in the early $19^{\text {th }}$ century that fiqh received more impetus to develop as the most popular branch of Islamic sciences in Indonesia.

The most popular books of fiqh in Indonesia are al-Taqrîb fí al-Fiqh, Fath $a$ al-Muîin,

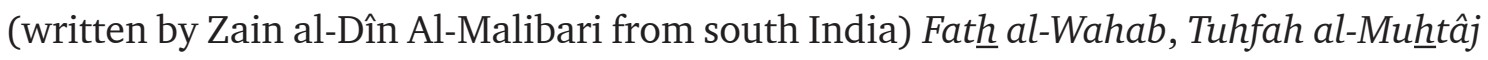
(written by Ibn Hajar al-Haitami), Safinnah al-Najah, Sullam Taufiq Minhâj al-Qawim, alHawasyi al-Madaniyah, Bajuri, Iqna' and Tausi'. The last three books are explanations (sharh) of Taqrîb fi al-Fiqh. These books are part of the curriculum in the pesantrens. Bigger books like I'ânah al-Thâlibîn, the explanation (sharh) of Fath al-Mu'în, Sharh Muhazzab by Imam Nawawi and Nihâyah al-Muhtâj are only being used as the books of reference by the ulamas. 
M. Mujab: The Role of Pesantren on The Development Islamic Science in Indonesia

The Books of Fiqih and Ushûl Fiqh which used in most of the Traditional School in Indonesia ${ }^{28}$

\begin{tabular}{|c|c|c|c|c|c|c|c|}
\hline Region & $\begin{array}{c}\text { Suma } \\
\text { tera }\end{array}$ & $\begin{array}{c}\text { South } \\
\text { Kalimantan }\end{array}$ & $\begin{array}{l}\text { West } \\
\text { Java }\end{array}$ & \begin{tabular}{|c|} 
Center \\
of Java
\end{tabular} & $\begin{array}{l}\text { East } \\
\text { Java }\end{array}$ & Total & Level \\
\hline $\begin{array}{l}\text { Number of Pesantren } \\
\text { Fiaih }\end{array}$ & 4 & 3 & 9 & 12 & 18 & 46 & \\
\hline Fath al-Mu'in & 2 & 1 & 7 & 6 & 16 & 32 & Aliyah \\
\hline I'ânah Thâlibîn & 2 & 2 & 0 & 0 & 0 & 4 & \\
\hline Taqrîb & 2 & 0 & 6 & 5 & 7 & 20 & Tsanawiyah \\
\hline Fath al-Qarîb & 2 & 1 & 4 & 7 & 9 & 23 & Aliyah \\
\hline Kifyah al-Akhyâr & 1 & 0 & 6 & 4 & 7 & 18 & $\begin{array}{l}\text { Tsanawiyah/ } \\
\text { Aliyah }\end{array}$ \\
\hline Bajuri & 1 & 0 & 1 & 0 & 1 & 3 & \\
\hline Igna' & 0 & 1 & 1 & 0 & 5 & 7 & \\
\hline Minhaj al-Thâlibîn & 2 & 0 & 2 & 0 & 1 & 5 & Aliyah \\
\hline Minhaj al-Thullâb & 0 & 0 & 0 & 0 & 1 & 1 & \\
\hline Fath al-Wahab & 0 & 1 & 5 & 4 & 10 & 20 & Aliyah \\
\hline Māhalli & 4 & 1 & 1 & 2 & 1 & 9 & Aliyah \\
\hline Minhâj al-Qawin & 0 & 0 & 2 & 2 & 3 & 7 & \\
\hline Safinah & 1 & 0 & 6 & 7 & 7 & 21 & Tsanawiyah \\
\hline Kasyfat al-Saja & 0 & 0 & 1 & 0 & 3 & 4 & \\
\hline Sullâm al-Taufìq & 0 & 1 & 5 & 2 & 13 & 21 & Tsanawiyah \\
\hline Tahrir & 0 & 1 & 2 & 1 & 5 & 9 & Aliyah \\
\hline Riyadh al-Badiah & 0 & 0 & 2 & 1 & 3 & 6 & \\
\hline Sullâm al-Munajat & 0 & 0 & 2 & 1 & 2 & 5 & \\
\hline Uqud al-Lujain & 0 & 0 & 1 & 1 & 2 & 4 & Tsanawiyah \\
\hline Sittin/Syarah Sittin & 0 & 1 & 2 & 0 & 0 & 3 & \\
\hline Muhadzab & 0 & 0 & 0 & 1 & 2 & 3 & \\
\hline $\begin{array}{l}\text { Bughyat al- } \\
\text { Mustarsyidîn }\end{array}$ & 0 & 0 & 1 & 0 & 2 & 3 & Tsanawiyah \\
\hline Mabâdi' Fiqhiyah & 0 & 0 & 1 & 2 & 5 & 8 & Tsanawiyah \\
\hline Fiqh al-Wadhih & 0 & 0 & 0 & 1 & 3 & 4 & \\
\hline Ushûl al-Fiqh & & & & & & & \\
\hline $\begin{array}{l}\text { Waraqat/Syarah/ } \\
\text { al-Waraqat }\end{array}$ & 2 & 1 & 6 & 1 & 2 & 12 & $\begin{array}{l}\text { Aliyaah/ } \\
\text { Khawash }\end{array}$ \\
\hline Lahtâ'if al-Isyârat & 1 & 0 & 3 & 0 & 6 & 10 & \\
\hline Jam' al-Jawâmi' & 1 & 0 & 6 & 1 & 2 & 10 & $\begin{array}{l}\text { Khawash } \\
\text { Aliyah/ }\end{array}$ \\
\hline Luma' & 1 & 0 & 2 & 1 & 3 & 7 & Khawash \\
\hline $\begin{array}{l}\text { Al-Asybah wa al- } \\
\text { Nazhâ'ir }\end{array}$ & 0 & 0 & 1 & 1 & 4 & 5 & Khawash \\
\hline Bayân & 0 & 0 & 1 & 0 & 2 & 3 & $\begin{array}{l}\text { Tsanawiyah/ } \\
\text { Aliyah }\end{array}$ \\
\hline Bidâyah al-Mujtahîd & 0 & 0 & 2 & 0 & 0 & 2 & Khawash \\
\hline
\end{tabular}

${ }^{28}$ Ibid., p. 115. 
After the arrival of the modernists in Indonesia in the early 1900s, there are a number of books on fiqh written by them that are said to be slightly different from those early books written by the traditionalists. These books are like Bidâyah al-Mujtahîd written by Ibn Rushd and Fiqh al-Sunnah, comprising of 14 volumes written by a modern Egyptian writer Sayyid Sabiq. These books soon became very popular in Indonesia and have become the compulsory subject in the pesantrens. These books have also been translated into Indonesian.

Ushûl fiqh is another branch of Islamic science that is also very popular in Indonesia, placed second after fiqh. There is a great interest among the Indonesian.

Ushûl fiqh is another branch of Islamic science that is also very popular in Indonesia, placed second after fiqh. There is a great interest among the Indonesian ulamas in studying the subject. But the number of books on this subject in Indonesia are lesser than the number of books on fiqh. Al-Waraqat fí Ushûl Fiqh of Imam al-Haramain 'Abd al-Malik al-Juwainî (d. $487 \mathrm{AH} / 1085 \mathrm{AD}$ ) and its explanation (sharh), Latha'if al-Isyarah written by 'Abd al-Hamid ibn Muhammad Ali al-Qudûsî (d.1334AH/1916AD), are two books on Ushûl Fiqh prescribed in the pesantrens and madrasahs in Indonesia. At the higher level, al-Luma' fî Ushûl alFiqh of Ibrâhîm bin 'Alî Syîrâzî al-Fairuzâbadî is used. Jam' al-Jawami' of Taj al-Dîn 'Abd al-Wahab al-Subki that contains the texts of the basic of Islamic law is used at the highest level. Al-Ashbah wa al-Naza'ir fĩ Qawa'id wa Furu' Fiqh al-Imâm Syafi'iyah of Jalâl al-Dîn al-Shuyuthi is also an important book on Ushûl Fiqh that is widely used in Indonesia. ${ }^{29} \mathrm{Al}$ Umm and al-Risalah, two books of Imam Shafi'i, are important books of the Shafi'i School. But these two books are not used as part of the syllabus in the pesantrens. This is quite strange as in Indonesia, Shafi'i School is followed by the majority of the Muslims.

\section{Conclusion}

Although Islam entered in Indonesia some centuries earlier, but the significant development of Islamic sciences in Indonesia occurred only after the $19^{\text {th }}$ century. The geographical position of Indonesia has isolated Indonesia from the center of Islam in the Middle East. Historical records have reinforced the view that the stumbling block for the development of Islamic sciences in Indonesia was the period of 300 years of Dutch occupation in this country. However, there are three phenomenal pesantrens in Indonesia succeed to develop Islamic science and became reference for other pesantrens such as Pesantren Tebuireng, Pesantren Bahrul Ulum and Pesantren Darussalam Gontor.

In general we can conclude that the role of pesantren in Indonesia in imparting Islamic sciences among the Muslims masses is very significant. It was Tebuireng at first that has introduced modern sciences into Islamic traditional institutions in Indonesia because its founders realized that education should also meet the needs of a new society, which was

${ }^{29}$ Ibid., pp. 117-124. 
M. Mujab: The Role of Pesantren on The Development Islamic Science in Indonesia

under the impact of the modern education. The pesantrens above then, adjust their academic curriculum based on the demand and putting general science and knowledge into curriculum.

New strategies have been devised by some Pesantrens to overcome the problems created by the system. Pesantrens like Tebuireng and other Islamic educationalinstitutions founded their own private university to ensure continuation of education for the students of their highest classes, the university as known as Universitas Hasyim Asy'ari, pesantren Bahrul Ulum has also Bahrul UlumUniversity and Gontor has Institut Studi Islam Darusaalam (ISID - at university level too). Establishing university is, however, easier to achieve acceptable standard of education and getting recognition from the government based on satisfactory standards. This new type of private Islamic course at university level has made great advances for pesantrens in Indonesia.

\section{References}

Azra Azyumardi. Jaringan Ulama Timur Tengah dan Kepulauan Nusantara Abad XVII dan XVIII. Bandung: Mizan. 1994.

Boland B.J. The Struggle of Islam in Modern Indonesia. Leiden: Martinus Nijhoff. 1971.

Bruinessen, Martin Van. Kitab Kuning Pesantren dan Tarekat. Bandung: Mizan. 1999.

Dhofier, Zamakhsyari. Tradisi Pesantren. Jakarta: LP3ES. 1982.

Direktori Pesantren. Jakarta: P3M. 1986.

Mastuhu. Dinamika Sistem Pendidikan Pesantren. Jakarta: INIS. 1994.

Rahardjo, M. Dawam. Pesantren dan Pembaharuan. Jakarta: LP3ES. 1995.

Ridlwan, Nasir M. Dinamika Sistem Pendidikan. Surabaya: Central Media. 1996.

Wahid, Marzuki, Suwendi, and Saifuddin Zuhri. Pesantren Masa Depan. Bandung: Pustaka. 1999. 